\title{
Water Use Effectiveness Is Enhanced Using Film Mulch Through Increasing Transpiration and Decreasing Evapotranspiration
}

\author{
Qianxi Shen ${ }^{1,2}$, Risheng Ding ${ }^{1,2, *(\mathbb{D})}$, Taisheng Du ${ }^{1,2}$, Ling Tong ${ }^{1,2}$ and Sien Li ${ }^{1,2}$ \\ 1 Center for Agricultural Water Research in China, China Agricultural University, Beijing 100083, China; \\ 18813072710@163.com (Q.S.); dutaisheng@cau.edu.cn (T.D.); tongling2001@cau.edu.cn (L.T.); \\ lisien@cau.edu.cn (S.L.) \\ 2 Wuwei Experimental Station for Efficient Water Use in Agriculture, Ministry of Agriculture and Rural \\ Affairs, Wuwei 733000, China \\ * Correspondence: dingrsh@cau.edu.cn
}

Received: 19 April 2019; Accepted: 10 May 2019; Published: 1 June 2019

\begin{abstract}
Water shortage is a main limitation of crop growth and yield in drought northwest China, which is an important area of seed maize growth. Plastic film mulch is widely adopted to reduce soil evaporation $(E)$ and conserve water resources, which changes evapotranspiration $(E T)$ and its components, $E$ and transpiration ( $T r$ ) and crop growth. The AquaCrop model, one of widely used crop models powered by water, can well simulate crop ET components and growth. However, there are few studies that examine ET partitioning and growth with and without plastic film mulch. The calibrated AquaCrop model was used to partition ET and simulate growth of seed maize with and without plastic film mulch in a drought region of northwest China in 2014 and 2015. The AquaCrop model can well simulate canopy cover curve (CC), and the dynamic and accumulated courses of ET and ET components. Plastic film mulch could advance the growth stage of seed maize and reduce seasoned ET. The initial stage with plastic film mulch was 37-42 days, while it was 46-48 days for no-mulch. Plastic film mulch increased $\operatorname{Tr}$ by $14.16 \%$ and $14.48 \%$ and significantly decreased $E$ by $57.25 \%$ and $34.28 \%$ in 2014 and 2015, respectively, resulting in the reduction of seasonal total ET. Plastic film mulch increased averaged mid-season crop coefficient for transpiration $\left(K_{c}{ }_{T r}\right)$ by $0.88 \%$ and decreased soil evaporation coefficient $(\mathrm{Ke})$ by $62.50 \%$. Collectively, the results suggest that, in comparison with no-mulch, plastic film mulch advanced crop growth, and decreased total ET and increased $\operatorname{Tr}$ related with crop production, i.e., improve water use effectiveness.
\end{abstract}

Keywords: plastic film mulch; water use effectiveness; evapotranspiration; transpiration; AquaCrop model; maize

\section{Introduction}

Water resources scarcity is the main cause of crop failure [1]. The trend is further worsened by climate change, since climate change projections indicate that vapor pressure deficit (VPD), and thus, evaporation demand, will become an expected increase [2]. Crop evapotranspiration (ET) is the largest proportion of ET, precipitation and irrigation in cropland water balance component $[3,4]$ because more than $90 \%$ of water used in agriculture is lost through soil evaporation and crop transpiration, referred to as evapotranspiration [5]. Soil evaporation cannot promote the increase of crop yield and should be controlled by management measures (e.g., plastic film mulch) [6,7]. On the contrary, transpiration occurs simultaneously through stomata and photosynthesis in leaves and is closely related to crop growth and production [8], whereas the two independent processes $\operatorname{Tr}$ and $E$ occur simultaneously and are difficult to distinguish [9]. Therefore, in order to better understand the water 
consumption law of seed maize and formulate accurate irrigation scheduling, so as to improve the water use effectiveness (EUW, means effective use of water, usually represents a process, and not water use efficiency (WUE)) and save water resources [10], ET needs to be accurately partitioned and growth simulated through models.

There are many crop models which have been widely used to estimate ET and its components and crop growth, such as DSSAT [11], WOFOST [12], APSIM [13], EPIC [14,15], WAVES [16], and Crop-Syst [17]. However, these models are complex and often require a large number of hard-to-obtain input variables and calibration parameters. The AquaCrop model is the newest international water-driven crop model developed by $F A O$ to estimate ET and crop growth and yield $[18,19]$. The AquaCrop model can simulate canopy cover and estimate $T r$ and $E$ depending upon canopy cover curve. The AquaCrop model was widely used in annual field crops, e.g., Stricevic et al., Nyakudya and Stroosnijder, Abedinpour et al., Hsiao et al., and Paredes et al. [20-24] for maize; Mkhabela and Bullock, Wang et al., Andarzian et al., Iqbal et al., and Toumi et al. [25-29] for wheat; Linker et al., and Garcia-Vila et al. [30,31] for cotton; Maniruzzaman et al. [32] for rice; Todorovic et al., and Stricevic et al. [20,33] for sunflowers; Araya et al. [34] for barley, and others.

In the drought region of northwest China, a major yield limiting factor is water shortage, where seed maize plays an important role in major cereal crops because of its high price and income. To save water resources by reducing soil evaporation in the field, plastic film mulch practice has been widely used in this area since this century [35-37]. Many studies indicate that plastic film mulch can not only reduce soil evaporation, but also accelerate crop growth due to increased soil temperature and weeds control [37,38]. Several studies used the AquaCrop model to partition ET into $E$ and $\operatorname{Tr}$ [24,39-41]. However, there are few studies that used the AquaCrop model to partition $E T$ and investigate crop growth with and without plastic film mulch.

The objectives of this study were to quantify the differences of ET partitioning and maize growth, and to analyze the causes of the differences between mulched and unmulched plastic film field using the AquaCrop model.

\section{Material and Methods}

\subsection{Experimental Site and Design}

The experimental observation occurred, respectively, in 2014 and 2015 from April to September in northwest China's Gansu province Wuwei city the Shiyanghe Experimental Station for Water-saving in Agriculture and Ecology of China Agricultural University (N $37^{\circ} 51^{\prime}$, E $102^{\circ} 52^{\prime}$, and $1581 \mathrm{~m}$ elevation). This region is typical of arid continental temperate climate, where it is rich in light and heat resources. The average annual sunshine time is more than $3000 \mathrm{~h}$, and the hottest monthly daily temperature is $29^{\circ} \mathrm{C}$ in July, with more than 150 days of frost-free period. However, the region is short of water, with an average annual precipitation of $164 \mathrm{~mm}$ and an average annual evaporation from a free water surface of $2000 \mathrm{~mm}$. The groundwater table is $30-40 \mathrm{~m}$ below the ground surface. For sandy loam soil and corresponding mean soil dry bulk density of $1.40 \mathrm{~g} \cdot \mathrm{cm}^{-3}$, field capacity of $30 \%$, and permanent wilting point of $11 \%$ for the $0-100 \mathrm{~cm}$ layers, the average saturated water content of $0.41 \mathrm{~cm}^{3} \cdot \mathrm{cm}^{-3}$. Saturated hydraulic conductivity is $500 \mathrm{~mm} \cdot \mathrm{d}^{-1}$.

The experimental design was a completely random design, including two treatments with and without plastic film mulch $(M, N)$. Each treatment was repeated three times with a length of $9 \mathrm{~m}$ from north to south and $12.6 \mathrm{~m}$ from east to west. The bare soil surface was mulched with a transparent plastic thin film strip every $20 \mathrm{~cm}$. The plastic film thickness was $0.04 \mathrm{~mm}$ and the width was $140 \mathrm{~cm}$. Each film strip was mulched with four rows of seed maize. For seed maize, holes with a diameter of $5.0 \mathrm{~cm}$, a plant spacing of $25 \mathrm{~cm}$, and a row spacing of $40 \mathrm{~cm}$ were opened on the plastic film to sowing of single row male parents and five rows female parents, and there were no maize plants in the bare ground. Therefore, due to the existence of bare soil and holes, the actual mulching rate was 0.70 . In 2014 and 2015, seed maize was sown on April 15 and 17, and harvested on September 20. 
The experimental irrigation method was border-irrigation with uniform water infiltration according to the local actual agricultural production. The irrigation schedule in the experiment was estimated by subtracting precipitation from preceding ET calculated by crop coefficient method, and the water deficit was calculated by the difference between root area, field capacity and observed soil water content $(S W C)$. The actual irrigation water in the experiment was measured and recorded by turbine flow meters. The precipitation and irrigation schedule in 2014 and 2015 are shown in Table 1. According to the local practice, the ratio of fertilizers application for $420 \mathrm{~kg} \cdot \mathrm{ha}^{-1} \mathrm{~N}$ in 2014 and $390 \mathrm{~kg} \cdot \mathrm{ha}^{-1} \mathrm{~N}$ in 2015. At the same time, $240 \mathrm{~kg} \cdot \mathrm{ha}^{-1} \mathrm{P}_{2} \mathrm{O}_{5}$ and $50 \mathrm{~kg} \cdot \mathrm{ha}^{-1} \mathrm{~K}_{2} \mathrm{O}$ were applied in each year. Full doses of potassium and phosphate were applied prior to seeding, with half of the $\mathrm{N}$ used as a base treatment at seeding and the rest applied during the first irrigation.

Table 1. Irrigation schedules for treatments with and without plastic film mulch ( $\mathrm{M}$ and $\mathrm{N})$ and precipitation during the growth season of seed maize in 2014 and 2015.

\begin{tabular}{|c|c|c|c|c|c|c|c|c|c|c|c|c|c|c|c|c|c|}
\hline \multirow{2}{*}{ Years } & \multirow{2}{*}{ Treatments } & \multicolumn{13}{|c|}{ Irrigation Schedules and Irrigation Depth (mm) } & \multirow{2}{*}{$\begin{array}{c}\text { Irrigation } \\
(I)\end{array}$} & \multirow{2}{*}{$\begin{array}{c}\text { Precipitation } \\
(P) \\
(\mathrm{mm})\end{array}$} & \multirow{2}{*}{$\begin{array}{l}I+P \\
(\mathrm{~mm})\end{array}$} \\
\hline & & $6 / 8$ & $6 / 13$ & $6 / 27$ & $7 / 7$ & $7 / 12$ & $7 / 19$ & $7 / 25$ & $7 / 31$ & $8 / 6$ & $8 / 15$ & $8 / 20$ & $8 / 21$ & $9 / 2$ & & & \\
\hline \multirow{2}{*}{2014} & M & & 80.6 & & & 80.6 & & & 80.6 & & & & 30.7 & & 272.5 & 241.0 & 513.5 \\
\hline & $\mathrm{N}$ & & 86.4 & & 98.6 & & & 98.6 & & & & & 53.8 & & 337.4 & 241.0 & 578.4 \\
\hline \multirow{2}{*}{2015} & M & 69.1 & & 53.6 & & & 72.9 & & & 87.2 & & 51.9 & & 90.6 & 425.3 & 150.6 & 575.9 \\
\hline & $\mathrm{N}$ & 69.1 & & 75.7 & & & 77.0 & & & 78.5 & & 72.2 & & 102.9 & 475.4 & 150.6 & 626.0 \\
\hline
\end{tabular}

\subsection{Data Measurements}

\subsubsection{Meteorological Data}

Meteorological data, including solar radiation $\left(R_{s}, \mathrm{~W} \cdot \mathrm{m}^{-2}\right)$, precipitation $(P, \mathrm{~mm})$, air temperature $\left(T,{ }^{\circ} \mathrm{C}\right)$ relative humidity $(R H, \%)$, and wind speed $\left(u_{2}, \mathrm{~m} \cdot \mathrm{s}^{-1}\right)$, were continuously measured at a standard automatic weather station (Hobo, Onset Computer Corp, Bourne, MA, USA), $2.0 \mathrm{~m}$ above the ground. The data were collected every $5 \mathrm{~s}$, and the data recorder recorded an average of $15 \mathrm{~min}$. The FAO Penman-Monteith method [38] was used to calculate daily reference crop evapotranspiration $\left(E T_{0}, \mathrm{~mm}\right)$. The daily maximum, minimum temperatures, precipitation, and $E T_{0}$ for each growing season are shown in Figure 1.
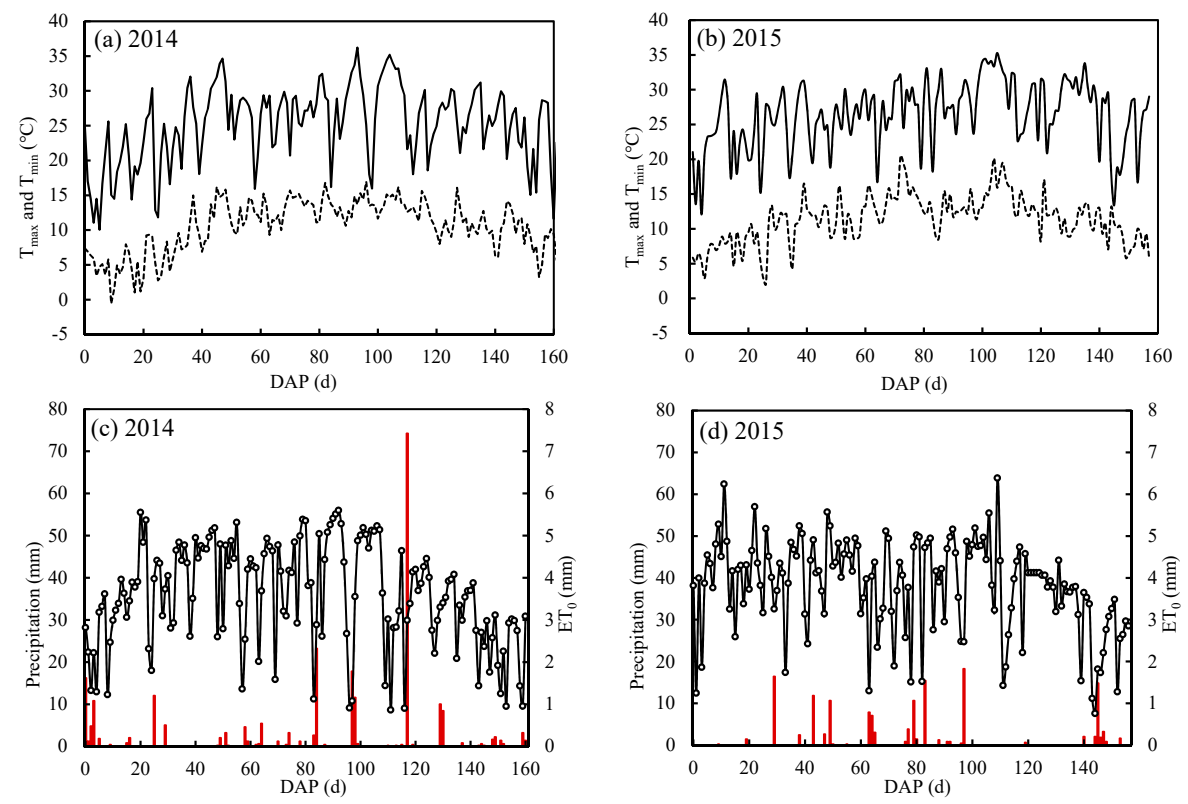

Figure 1. Variations in daily meteorological data against days after planting (DAP) of seed maize in 2014 and 2015, including maximum $\left(T_{\max },-\right)$ and minimum $\left(T_{\min },----\right)$ air temperature, precipitation (I), and reference evapotranspiration (ET, - - - $)$. 


\subsubsection{Canopy Cover}

In 2015, canopy cover (CC) was directly measured by an overhead digital camera, and image analysis software was used to calculate the ratio of weekly green leaf pixels in each plot to the whole picture. In 2014, it was derived from the leaf area index ( $L A I)$ by the following empirical equation, given by Hsiao et al. [23]:

$$
C C=1.005\left[1-\exp (1-\exp (-0.6 L A I)]^{1.2}\right.
$$

Five maize plants were randomly selected and the plant height of each treatment plot was measured every 10 days. The leaf area index (LAI) was taken to be leaf area per unit of area.

\subsubsection{Soil Water Content}

Volumetric soil water content (SWC) was measured by a tubular soil water probes (Trime-TDR, Imko, Gmbh, Ettlingen, Germany). The maximum soil depth was $1.0 \mathrm{~m}$, with an interval of $0.2 \mathrm{~m}$ per week. Each plot was fitted with two detection tubes, one in the mulched area and the other in the bare soil area. The frequency of the SWC measurements would increase before and after each irrigation and precipitation.

\subsubsection{Evapotranspiration}

In this study, the water balance equation was used to estimate ET.

$$
E T=P+I+W-D-R-\Delta S
$$

where $P$ is the precipitation $(\mathrm{mm}), I$ is the irrigation quantity $(\mathrm{mm}), W$ is the groundwater flow into the root zone $(\mathrm{mm}), D$ is the drainage $(\mathrm{mm}), R$ is the surface runoff $(\mathrm{mm}), \Delta S$ is the change of soil moisture storage. The terrain of the experimental site was flat and the precipitation was not strong, so surface runoff and deep drainage could be ignored. $W$ could also be ignored, as the groundwater table was 30-40 m below the ground surface, which is not enough to affected the growth of seed maize. Therefore, the Equation (2) can be simplified as:

$$
\begin{gathered}
E T=P+I-\Delta S \\
\Delta S=1000 \times Z \times\left(\theta_{2}-\theta_{1}\right)
\end{gathered}
$$

where $Z$ is the depth of root zone $(\mathrm{m})$ with the change of plant growth, and $\theta_{2}$ and $\theta_{1}$ are average soil water contents in the root zone at two measurement times $\left(\mathrm{m}^{3} \cdot \mathrm{m}^{-3}\right)$.

\subsection{Model Description}

\subsubsection{Model Principles and Algorithms}

The AquaCrop model is a crop model powered by water. It first calculates transpiration and then converts it into biomass through water productivity, which combines four sub-models: (1) The atmosphere sub-model, treatment of rainfall, evaporative demand (reference evapotranspiration, $E T_{0}$ ), and $\mathrm{CO}_{2}$ concentration; (2) the development, growth and yield of crops; (3) the management sub-model, including irrigation and fertilization; and (4) the balance with soil water. The AquaCrop model use a " $\mathrm{Kc}-E T_{0}$ " approach to estimate $\operatorname{Tr}$ and $E$, depending on the daily time step used for canopy cover. $\operatorname{Tr}$ is calculated as:

$$
\operatorname{Tr}=C C^{*} K c_{T r, x} E T_{0}
$$

where $E T_{0}$ is reference evapotranspiration $(\mathrm{mm})$ calculated using the $F A O$ Penman-Monteith method $\left(\mathrm{mm} \cdot \mathrm{d}^{-1}\right), K c_{T r, x}$ is the maximum standard crop transpiration coefficient (non-dimensional) (well-watered soil and complete canopy, canopy cover $=100 \%$ ), and $C C^{*}$ is the actual crop canopy cover (\%) adjusted for micro-advective effects. The actual transpiration is obtained by adjusting $\operatorname{Tr}$ to soil 
water stress conditions using the water stress coefficient $K s(0-1)$, i.e., $\operatorname{Tr}_{a d j}=K s \Delta T r$. The coefficient $K s$ describes the effects of soil water stress on the following crop growth processes including water $\operatorname{logging}\left(K s_{a e r}\right)$, stomatal closure $\left(K s_{s t o}\right)$ and soil salinity stress $\left(K s_{\text {salt }}\right)$. There was no water stress in this study, so the effect of $K s$ was not considered.

$C C^{*}$ is calculated as:

$$
C C^{*}=1.72 C C-C C^{2}+0.30 C C^{3}
$$

Under optimal conditions, the development and senescence of the green canopy is described as:

$$
\begin{gathered}
C C=C C_{0} e^{t C G C} \text { for } C C \leq C C_{x} / 2 \\
C C=C C_{x}-0.25 \frac{\left(C C_{x}\right)^{2}}{C C_{0}} e^{-t C G C} \text { for } C C>C C_{x} / 2 \\
C C=C C_{x}\left[1-0.05\left(e^{\frac{C D C}{C C} t}-1\right)\right] \text { for } C C \text { decline }
\end{gathered}
$$

where $C C_{0}$ is the initial canopy cover at $90 \%$ emergence, $C C_{x}$ is the maximum canopy cover, $C G C$ is the canopy growth coefficient $\left(\mathrm{d}^{-1}\right)$, and $t$ is time $(\mathrm{d})$.

$C G C$ and $C D C$ are the two most important parameters for building up the $C C$, which are modified by soil water stress, as follows:

$$
\begin{gathered}
C G C_{a d j}=K s_{\text {exp }} C G C \\
C D C_{a d j}=\left(1-K s^{8}{ }_{s e n}\right) C D C
\end{gathered}
$$

where $C G C_{a d j}$ is $C G C$ adjusted for water stress $\left(\mathrm{d}^{-1}\right), K_{s_{\exp }}$ is the water stress coefficient for canopy expansion (0-1), $C D C_{a d j}$ is $C D C$ adjusted for water stress $\left(\mathrm{d}^{-1}\right)$, and $K s_{s e n}$ is the water stress coefficient for early canopy senescence (0-1).

The soil evaporation is also obtained by $C C^{*}$ and $E T_{0}$ :

$$
E=K r\left(1-C C^{*}\right) K e_{x} E T_{0}
$$

The calculation equation of soil evaporation under plastic film mulch is as follows:

$$
E=K r\left(1-f_{m} f_{r \text { mulch }}\right)\left(1-C C^{*}\right) K e_{x} E T_{0}
$$

where $K e_{x}$ is the maximum soil evaporation coefficient (non-dimensional) of completely wet and unshaded soil surface, and AquaCrop model defaults to 1.10. $K r$ is the evaporation reduction coefficient $(0-1)$, and when the surface soil moisture is insufficient, $K r<1$, in response to atmospheric evaporation requirements. $f_{m}$ is a regulator of the influence of mulch on soil evaporation, $f_{r \text { mulch }}$ is a fraction of the mulch $\left(f_{r \text { mulch }}=0.70\right)$.

\subsubsection{Parameters Sensitivity Analysis}

Accurate estimation of the AquaCrop model parameters is imperative for the accuracy of model outputs. A sensitivity analysis (SA) quantifies the impact of each uncertain factor (parameter or driving variable) on the variability of the model output and helps to understand the model's response to the changing behavior of these factors [42,43]. The SA methods are typically classified as local (i.e., derivative-based) or global [44]. A local SA only studies the influence of the change of one parameter on the output of the model and fixes all other parameters to an arbitrary value [42]. For these reasons, local methods are criticized as not suitable for nonlinear models [45]. A global SA (GSA) studies the average response of model output to changes in all parameters within a defined range. GSA technique fully considers parameter interactions or nonlinear responses, but requires repeated analysis of the changing parameter values in the parameter space, so it has high requirements for calculation and workload [46-48]. There are many existing GSA techniques, and this study used a combination of 
screening and variance-based methods. First, the Morris screening method [49]( was used to identify the parameters with the greatest influence. Then, using the Sobol' [50] sensitivity analysis method, the first-and higher-order effects of these most influential model parameters on the selected model output were quantified. In this study, the Morris SA method was used to screen the 29 input parameters affecting the AquaCrop model to select the first 15 input parameters that are most sensitive to $E$ and $T r$, and then the Sobol's SA method was used to analyze the global sensitivity of the selected 15 parameters. The 15 parameters were base temperature (BaseTemp), upper temperature (UpperTemp), soil water depletion factor for canopy expansion-upper threshold (PexpUpper), soil water depletion factor for canopy expansion - lower threshold (PexpLower), shape factor for water stress coefficient for canopy expansion (SFexp), soil water depletion factor for canopy senescence-upper threshold (PsenUpper), shape factor for water stress coefficient for canopy senescence (SFsen), crop coefficient when canopy is complete but prior to senescence $\left(K c_{T r, x}\right)$, minimum effective rooting depth (MinRootDepth), maximum effective rooting depth (MaxRootDepth), soil surface covered by an individual seedling at $90 \%$ emergence $\left(C C_{0}\right)$, canopy growth coefficient $(C G C)$, canopy decline coefficient $(C D C)$, the time from sowing to emergence (Emer), and the time from sowing to maturity (Mat), respectively. This combinatorial approach has been applied successfully in other studies (e.g., Kendall et al. [51]).

\subsubsection{Model calibration and Performance Evaluation}

The model was calibrated with the data during the field experiment in 2014 and validated in 2015, including ET and canopy cover. In order to evaluate the "goodness-of-fit" of the model, a variety of statistical methods were used, such as the previous study [24,52]. These indicators are computed from the pairs of measured and simulated values $M_{i}$ and $S_{i}(i=1,2, \ldots, n)$ whose means are, respectively, $\bar{M}$ and $\bar{S}$, thus:

$$
\begin{gathered}
R^{2}=\left\{\frac{\sum_{i=1}^{n}\left(M_{i}-\bar{M}\right)\left(S_{i}-\bar{S}\right)}{\left[\sum_{i=1}^{n}\left(M_{i}-\bar{M}\right)^{2}\right]^{0.5}\left[\sum_{i=1}^{n}\left(S_{i}-\bar{S}\right)^{2}\right]^{0.5}}\right\}^{2} \\
\text { RMSE }=\left[\frac{\sum_{i=1}^{n}\left(M_{i}-S_{i}\right)^{2}}{n}\right]^{0.5} \\
N R M S E=\frac{100}{\bar{M}}\left[\frac{\sum_{i=1}^{n}\left(M_{i}-S_{i}\right)^{2}}{n}\right]^{0.5} \\
E F=1.0-\frac{\sum_{i=1}^{n}\left(M_{i}-S_{i}\right)^{2}}{\sum_{i=1}^{n}\left(M_{i}-\bar{M}\right)^{2}} \\
d=1-\frac{\sum_{i=1}^{n}\left(S_{i}-M_{i}\right)^{2}}{\sum_{i=1}^{n}\left(\left|S_{i}-\bar{M}\right|+\left|M_{i}-\bar{M}\right|\right)^{2}}
\end{gathered}
$$

It indicates that when $d$ and $R^{2}$ values are close to 1 , the simulated values and the measured values are statistically close. It was reported that when the value of $R^{2}$ is $>0.5$, the simulation results are acceptable in the basin simulation. For the value of RMSE (root mean squared error), when the value of RMSE is close to zero, the consistency between simulation results and measured results is good. The value of NRMSE (normalized root mean squared error) may indicate the extent of agreement as a whole and has been applied in several studies. To test the quality of the modelling approach the Nash and Sutcliffe [53] modelling efficiency ( $E F$, non-dimensional) was used. Willmott's [54] index of agreement (d). However, none of the parameters can be generally accepted by most people as the evaluation criteria. We also recognize the complexity of partitioning evapotranspiration into evaporation and transpiration. Considering only one indicator is not comprehensive enough, so we considered all 
indicators including $d, R^{2}, R M S E, N R M S E$, and $E F$ to indicate the efficiency and accuracy of the models used in this study.

\section{Results and Discussion}

\subsection{Differences in Model Parameters Sensitivity and Calibration with and without Mulch}

The parameters sensitivity analysis of the AquaCrop model was shown in Figure 2. Since soil evaporation accounts for a small proportion in total ET and is less affected by crops, the values of parameters sensitivity were small and the sensitivity difference was small. Compared with the results of the unmulched treatment, plastic film mulch significantly reduced the sensitivity of 15 parameters, especially the global sensitivity, namely the interaction between parameters. As shown in Figure 2a, Mat is the most sensitive parameter under the condition of plastic film mulch. The GDDays (growing degree days) from sowing to maturity significantly influenced on $E$ through affecting maize growth stage. Plastic film mulch can reduce external environment influence on soil temperature, resulting in conservative GDDays for the whole growth period. As a result, the effect obviously reduced the global sensitivity of the parameters for the impact of $E$ due to the external environment change.
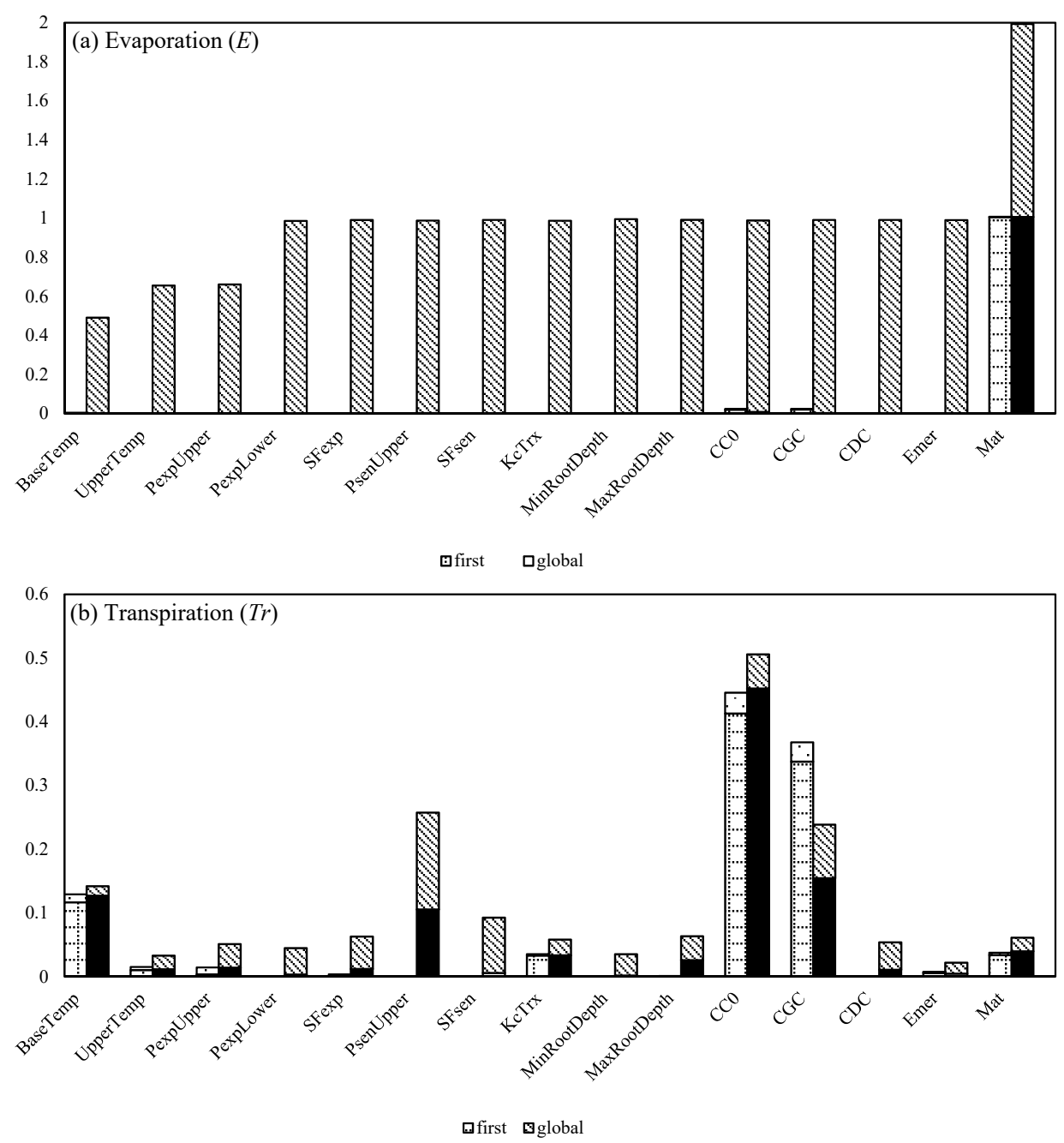

Figure 2. The Sobol' global sensitivity analysis (GSA, M, [; N, 目), and first order sensitivity analysis (SA, M, $\mathrm{G} ; \mathrm{N}, \mathbf{I})$ indices for the AquaCrop model output of evaporation $(E)$ and transpiration (Tr). Model input parameters were those sensitive by the Morris screening method. 
As shown in Figure 2b, for the $\operatorname{Tr}$ of seed maize, the sensitivity values of parameters were larger than $E$ due to the large proportion of $T r$ in total $E T$, and the sensitivity difference between parameters was large. The most sensitive parameter to $\operatorname{Tr}$ was $C C_{0}$. For seed maize, $C C_{0}$ was mainly related to planting density and canopy architecture, which was determined by field management and genotype, and was relatively conservative. So, although $C C_{0}$ was sensitive, it did not need to be adjusted in the later parameter calibration. The CGC was sensitive parameter next to $C C_{0}$. The CGC determines the shape of the CC curve of seed maize, and the simulation performance of ET by AquaCrop model depends on the simulation of CC curve. Therefore, we tuned the CGC during the parameter calibration process. The BaseTemp was also a relatively sensitive parameter, which affected Tr through the GDDays, thus affecting the whole growth process of seed maize. The sensitivity of most parameters (except CGC) for $\operatorname{Tr}$ was reduced by plastic film mulch, which was consistent with the effect of $E$. These results suggest that plastic film mulch could provide a relatively stable growth environment for seed maize and reduce the interference of the external environment on the growth of seed maize. The improved $C G C$ 's sensitivity by plastic film mulch might be because of $E T$ directly dependence on $C C$ determined by CGC.

The default and calibrated parameters of the AquaCrop model for both $\mathrm{M}$ and $\mathrm{N}$ treatments were shown in Table 2. The calibration of parameters was based on the above sensitivity analysis. Our study aims to use the AquaCrop model to partition ET on the basis of accurate simulation of $E T$, so we need to simulate ET as accurately as possible. The simulation accuracy of ET depends on the simulation of $C C$. Because $C G C, C D C$, and $C C_{x}$ affect the shape of $C C$ curve and the change process of $C C$, we gave different values of $C D C, C G C$, and $C C_{x}$ for each year and each treatment, respectively (Table 2). Plastic film mulch increased CGC from $1.15 \% \mathrm{GDD}^{-1}$ to $1.34 \% \mathrm{GDD}^{-1}$ in 2014 , and from $0.94 \% \mathrm{GDD}^{-1}$ to $1.18 \% \mathrm{GDD}^{-1}$ in 2015 , respectively. The larger the CGC, the faster growth of canopy, i.e., the less time it takes to reach a specific maximum CC. This corresponds to the fact that plastic film mulch can increase GDDays, advance the growth stage and shorten the time required for maturity. For $C D C$, plastic film mulch slightly improved the $C D C$, indicating it could accelerate the senescence and maturity of seed maize.

Table 2. Default and calibrated values of parameters of seed maize in the AquaCrop model.

\begin{tabular}{|c|c|c|c|c|c|}
\hline Description & Default Values & \multicolumn{4}{|c|}{ Calibrated Values } \\
\hline Base temperature, ${ }^{\circ} \mathrm{C}$ & 8 & \multicolumn{4}{|c|}{8} \\
\hline Upper temperature, ${ }^{\circ} \mathrm{C}$ & 30 & \multicolumn{4}{|c|}{30} \\
\hline Leaf growth threshold (PexpUpper) & 0.14 & \multicolumn{4}{|c|}{0.14} \\
\hline Leaf growth threshold (PexpLower) & 0.72 & \multicolumn{4}{|c|}{0.72} \\
\hline Leaf growth stress coefficient curve shape (SFexp) & 2.9 & \multicolumn{4}{|c|}{2.9} \\
\hline Minimum effective rooting depth (MinRootDepth), $\mathrm{m}$ & 0.3 & \multicolumn{4}{|c|}{0.3} \\
\hline Maximum effective rooting depth (MaxRootDepth), m & Up to 2.80 & \multicolumn{4}{|c|}{0.8} \\
\hline Senescence stress coefficient curve shape (SFsen) & 2.7 & \multicolumn{4}{|c|}{2.7} \\
\hline Canopy cover per seedling at $90 \%$ emergence $\left(C C_{0}\right), \mathrm{cm}^{2}$ per plant & 6.5 & \multicolumn{4}{|c|}{6.5} \\
\hline Stomatal conductance threshold (PstoUpper) & 0.69 & \multicolumn{4}{|c|}{0.45} \\
\hline Senescence stress coefficient (PsenUpper) & 0.69 & \multicolumn{4}{|c|}{0.5} \\
\hline Crop coefficient for transpiration at CC $=100 \%\left(K c_{T r, x}\right)$ & 1.05 & \multicolumn{4}{|c|}{1.25} \\
\hline Time from sowing to emergence (Emer), GDD, ${ }^{\circ} \mathrm{C} d \mathrm{~d}$ & $50-100$ & \multicolumn{4}{|c|}{$30-77$} \\
\hline \multirow[t]{2}{*}{ Time from sowing to maturity (Mat), GDD, ${ }^{\circ} \mathrm{C} \mathrm{d}$} & $\mathrm{T}_{\mathrm{SE}}{ }^{\mathrm{a}}+1450-1750$ & \multicolumn{4}{|c|}{$1551-1691$} \\
\hline & & $14 \mathrm{M}$ & $14 N$ & $15 \mathrm{M}$ & $15 N$ \\
\hline Canopy growth coefficient $(C G C), \%\left({ }^{\circ} \mathrm{C} \mathrm{d}\right)^{-1}$ & $1.2-1.3$ & 1.34 & 1.15 & 1.18 & 0.94 \\
\hline Canopy decline coefficient $(C D C), \%\left({ }^{\circ} \mathrm{C} \mathrm{d}\right)^{-1}$ & 1.0 & 0.29 & 0.29 & 0.68 & 0.66 \\
\hline Maximum canopy cover $\left(C C_{x}\right), \%$ & $65-99$ & 96 & 89 & 90 & 87 \\
\hline
\end{tabular}

${ }^{\mathrm{a}} \mathrm{T}_{\mathrm{SE}}$ is the time from sowing to emergence. Bold values are the specific calibrated parameters in this study.

Another important influencing factor is $K c_{T r, x}$ for accurately simulate $T r$ according to Equation (5). Our calibrated $K_{c} T_{T r} x$ was 1.25 , which was slightly higher than default (1.05) and previous values. The $K_{c} T_{r, x}$ was 1.08 for maize in Alpiarca, central Portugal by Paredes et al. [24]; the $K_{c}{ }_{T r, x}$ was 1.20 for seed maize in the same experimental site by Ran et al. [41]. In fact, $K c{ }_{T r}, x$ is the transpiration coefficient when $C C=100 \%$. For different years and different climatic conditions, the values of $K c T_{r, x}$ are different. For our study, the experimental site was the same as Ran et al. [41], but the experimental years were 
different, so the meteorological factors and other environmental conditions were different, resulting in slightly higher $K c_{T r, x}$ due to higher evaporative demand. The $K c_{T r, x}$ is similar to the $K_{c b \text { full }}$ in FAO 56, the basic crop coefficient in the middle of growth when the plant completely covers the ground or when $L A I>3$. The reference value of $K_{c b \text { full }}$ is 1.20 , which should be adjusted to local value according to relative humidity, wind speed, and plant height. The adjusted $K_{c b}$ full was higher than the default value for dry and hot climatic region. Our $K c_{T r}, x$ was close to the adjusted $K_{c b}$ full, indicating that the calibrated $K_{c}{ }_{T r, x}$ was reasonable.

The PstoUpper and PsenUpper were slightly less than the default value. Raes et al. [19] indicated that these two parameters will be reduced correspondingly if there were some stresses. For our study, the research area is located in the arid area of northwest China, where the climate is hot and dry, and there may be some stress in the growth period of seed maize.

\subsection{Differences in Canopy Cover and Growth With and without Mulch}

As shown in Figure 3, a good agreement was found between the simulated and measured CC for both $\mathrm{M}$ and $\mathrm{N}$ treatments for the two years. The goodness-of-fit indicators presented higher $R^{2}(>0.9)$ and lower RMSE of $3.6 \%$ and $4.1 \%$ in 2014 , and $4.1 \%$ and $4.0 \%$ in 2015 , respectively, for the two treatments (Table 3), which was slightly lower than previous studies, e.g., Hsiao et al. [23] [4.8-13.6\%] and Zeleke et al. [55] [8.4-12.4\%]. Farahani et al. [56] stated that the most logical pathway for a systematic calibration of AquaCrop is first and foremost to ensure a sound prediction of the canopy cover. Because field management could influence CGC and CDC [24,57], it was required to perform distinct parameterizations of the $C C$ curves for different field management. As mentioned above, in order to accurately simulate $C C$, we used different $C G C$ and $C D C$ values for different years and different treatment methods (Table 2), which was the same as the previous studies on maize and soybean $[24,39]$. Plastic film mulch advanced the growth stage of seed maize. This was clearly reflected in the length of the growth period, the initial stage for the M treatment was 37-42 days, while it was 46-48 days for the $\mathrm{N}$ treatment. These results show that plastic film mulch can accelerate the growth of maize canopy, improve the maximum canopy cover, and increase $C C_{x}$, thus increasing the effective utilization of water in seed maize.
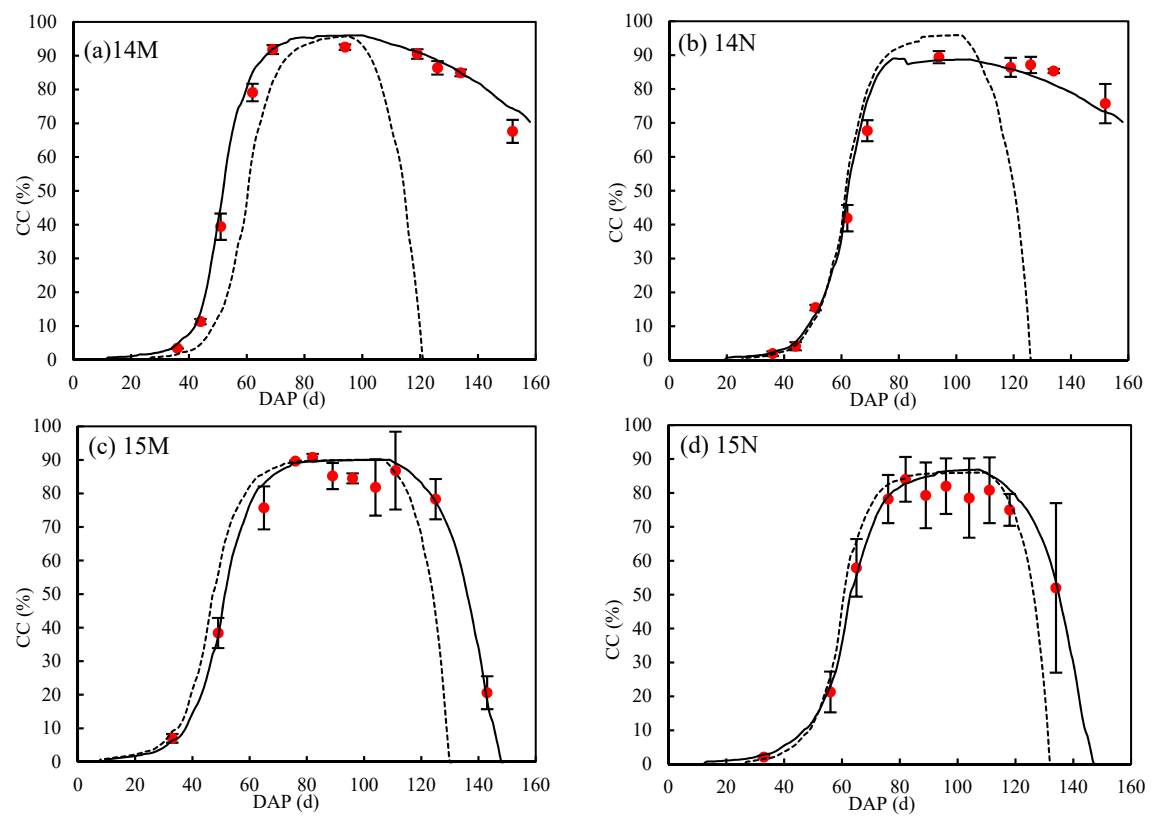

Figure 3. Simulated canopy cover (CC) using default (- - - -) and calibrated (-) parameters and measurements (•) of seed maize in 2014 and 2015. 
Table 3. Goodness-of-fit indicators between measurements and simulations for CC and accumulated evapotranspiration $(E T)$ of seed maize for treatments with and without plastic film mulch (M and N) in 2014 and 2015.

\begin{tabular}{|c|c|c|c|c|c|c|}
\hline Treatments & $N$ & $R^{2}$ & RMSE (\%/mm) & NRMSE (\%) & $E F$ & $d$ \\
\hline \multicolumn{7}{|l|}{ CC $(\%)$} \\
\hline $2014 \mathrm{M}$ & 10 & 1.00 & 3.6 & 5.5 & 0.99 & 1.00 \\
\hline $2014 \mathrm{~N}$ & 10 & 0.99 & 4.1 & 7.4 & 0.99 & 1.00 \\
\hline $2015 \mathrm{M}$ & 11 & 0.99 & 4.1 & 6.1 & 0.98 & 1.00 \\
\hline $2015 \mathrm{~N}$ & 11 & 1.00 & 4.0 & 6.7 & 0.98 & 1.00 \\
\hline \multicolumn{7}{|l|}{$E T(m m)$} \\
\hline $2014 \mathrm{M}$ & 12 & 0.98 & 17.827 & 8.1 & 0.99 & 1.00 \\
\hline $2014 \mathrm{~N}$ & 12 & 0.98 & 19.471 & 8.3 & 0.99 & 1.00 \\
\hline $2015 \mathrm{M}$ & 21 & 1.00 & 10.740 & 4.4 & 1.00 & 1.00 \\
\hline $2015 \mathrm{~N}$ & 21 & 0.99 & 15.198 & 6.3 & 0.99 & 1.00 \\
\hline
\end{tabular}

\subsection{Differences in Evapotranspiration with and without Mulch}

Although the simulated seasonal ET totals were slightly lower than the measurements for the two treatments of the two years, there was a good agreement between measured and simulated accumulated courses (Figure 4). The bias might be due to errors of measurement calculated using the water balance method [38]. The goodness-of-fit indicators were better, with the linear regression $R^{2}$ and RMSE of 0.98 and $17.827 \%$, and 0.98 and $19.471 \%$ in $2014,1.00$ and $10.740 \%$, and 0.99 and $15.198 \%$ in 2015, respectively, for the two treatments (Table 3), which was higher previous $R^{2}$ of 0.812 in Ran et al. [41]. In 2014, the simulated ET total was $512.6 \mathrm{~mm}$ for the $\mathrm{M}$ treatment, and $529.2 \mathrm{~mm}$ for the $\mathrm{N}$ treatment, respectively (Figure 4a,b). In 2015, the simulated $E T$ total was $526.4 \mathrm{~mm}$ for the M treatment, and $534.5 \mathrm{~mm}$ for the $\mathrm{N}$ treatment, respectively (Figure 4c,d). Compared with the total ET of the two treatments in two years, the ET value under the plastic film mulch condition was significantly lower than that under the non-mulched condition. These results indicate that plastic film mulch could decrease $E T$, which was consistent with previous study [58].
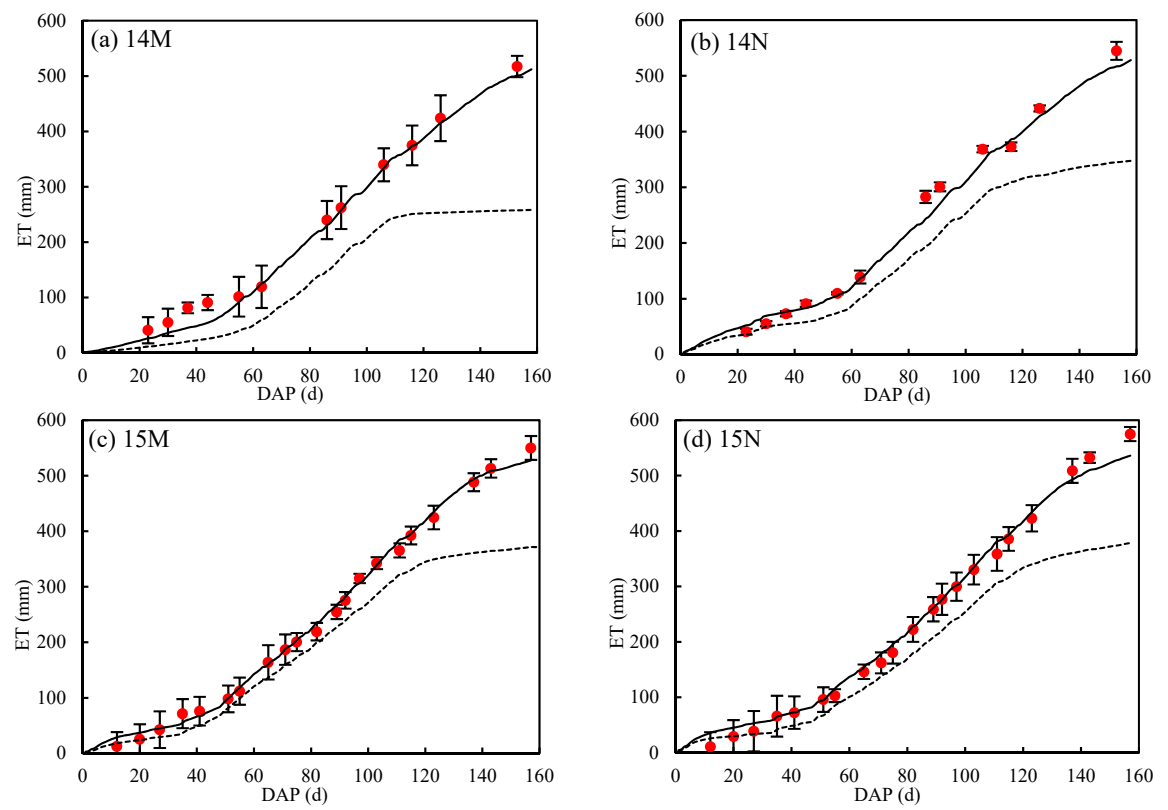

Figure 4. Simulated accumulated ET using default (- - - -) and calibrated (-) parameters and measurements (•) of seed maize in 2014 and 2015. 


\subsection{Differences in Transpiration and Evaporation with and without Mulch}

Seasonal variation of daily $\operatorname{Tr}$ was similar for the $\mathrm{M}$ and $\mathrm{N}$ treatments both years, but the $\mathrm{M}$ value was slightly higher the $\mathrm{N}$ treatment (Figure 5). Daily $T r$ increased rapidly from less than $1.0 \mathrm{~mm} \cdot \mathrm{d}^{-1}$ at the initial growth stage to $7.0-8.0 \mathrm{~mm} \cdot \mathrm{d}^{-1}$ at the mid-season growth stage. Subsequently, daily $\mathrm{Tr}$ decreased to less than $1.0 \mathrm{~mm} \cdot \mathrm{d}^{-1}$ at the end of season for the two treatments in 2014 and 2015 . The maximum daily $T r$ of $\mathrm{M}$ treatment is $3.2 \mathrm{~mm}$ larger than that of $\mathrm{N}$ treatment. $E$ was larger due to lower $C C$ at the initial and late-season stages before the development and after the senescence of maize canopy. After each precipitation or irrigation, there was a significant increase in $E$. In the mid-season with high $C C, E$ was lower or near to zero. Seasonal variation of daily $E$ was significantly different for the $\mathrm{M}$ and $\mathrm{N}$ treatments both years. The $\mathrm{N} E$ was distinctly higher than the $\mathrm{M}$ treatment, especially during the initial growth stage (Figure 5), which was attributed to the reduction of plastic film mulch. According to Equations (12) and (13), soil evaporation was not only dependent on the CC, but also related to the available water in the upper soil $(\mathrm{Kr} r)$ and the effect of film mulch $\left(f_{m}\right.$ and $f_{r}$ mulch $)$.
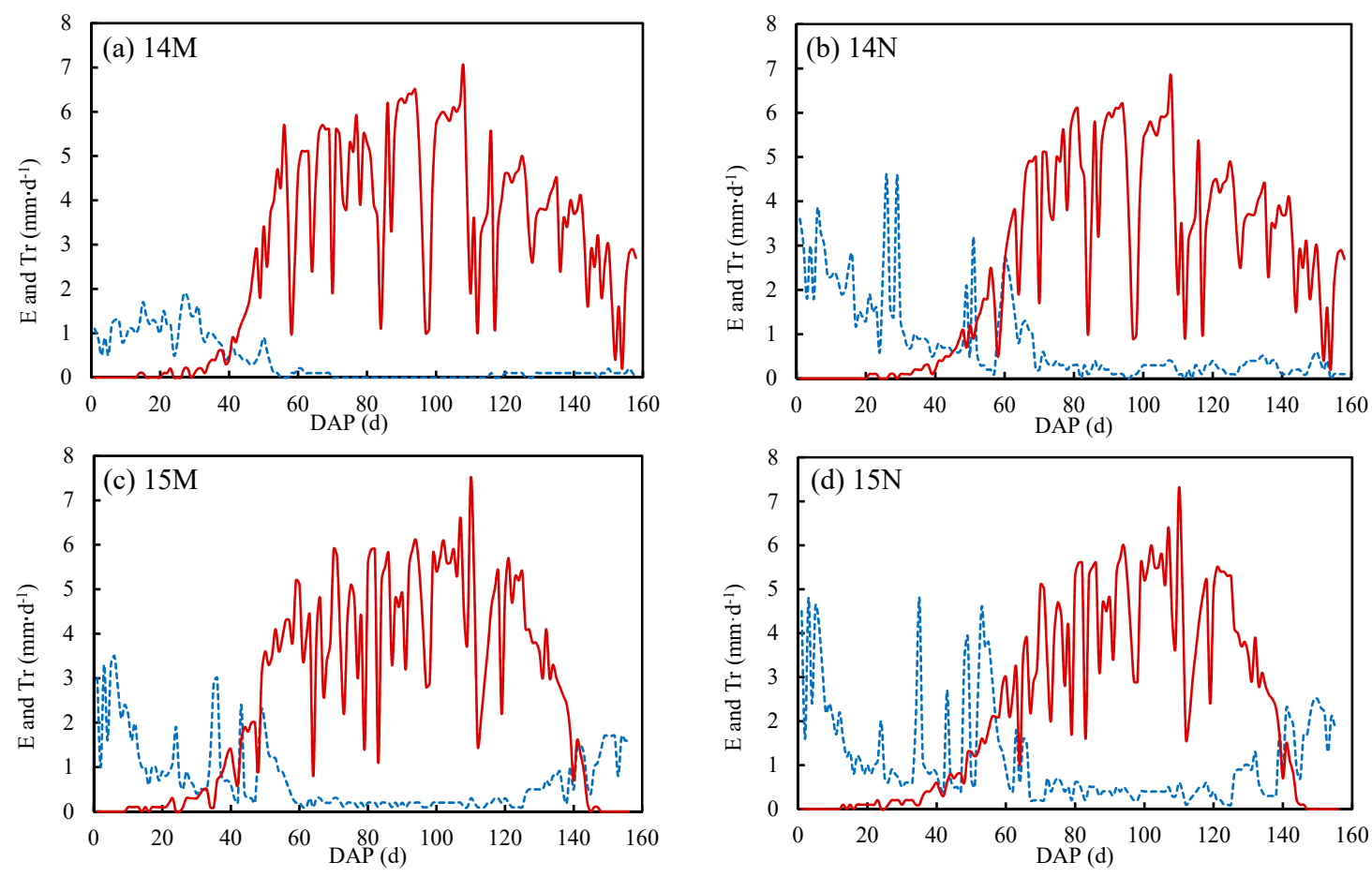

Figure 5. Variations in daily evaporation (E, - - - - ) and transpiration (Tr, - ) against DAP of seed maize for treatments with and without plastic film mulch (M and N) in 2014 and 2015.

Table 4 presented total and daily averaged $T r, E$, and $E T$ during the different growth stages and whole period. Total $T r$ accounted for most of total ET, with a highest value of $89.31 \%$ for the M treatment in 2014. The maximum of total $E$ was $32.80 \%$ for the $\mathrm{N}$ treatment in 2015 . Total $T r$ during the mid-season stage was the largest proportion, with $98.91 \%$ of total ET for the M treatment in 2014 . During the initial stage, E accounted for the largest proportion, with $91.65 \%$ of total $E T$ for the $\mathrm{N}$ treatment in 2014 when precipitation was much. Compared to the $\mathrm{N}$ treatment, the ratio of $\operatorname{Tr}$ to $E T$ increased from $75.77 \%$ to $89.31 \%$ in 2014 , and $67.20 \%$ to $78.12 \%$ in 2015 for the M treatment. The lower ratio of $\operatorname{Tr}$ to $E T$ in 2015 was due to pest and diseases. In conclusion, in 2014 and 2015, the ET was increased by $33 \mathrm{~mm}$ and $25 \mathrm{~mm}$, respectively, by $6.30 \%$ and $4.55 \%$. 
Table 4. ET, $T r, E$, and the percentage of $\operatorname{Tr}$ and $E$ to $E T$ in different growth stages for treatments with and without plastic film mulch (M and N) in 2014 and 2015.

\begin{tabular}{|c|c|c|c|c|c|c|c|c|c|c|c|}
\hline Treatments & Stage & DAP & Days & $\begin{array}{c}T r \\
(\mathrm{~mm})\end{array}$ & $\begin{array}{l}\text { Daily Tr } \\
\left(\mathrm{mm} \cdot \mathrm{d}^{-1}\right)\end{array}$ & $\begin{array}{c}E \\
(\mathrm{~mm})\end{array}$ & $\begin{array}{c}\text { Daily E } \\
\left(\mathbf{m m} \cdot \mathbf{d}^{-1}\right)\end{array}$ & $\begin{array}{c}E T \\
(\mathrm{~mm})\end{array}$ & $\begin{array}{c}\text { Daily } \\
E T \\
\left(\mathbf{m m} \cdot \mathrm{d}^{-1}\right)\end{array}$ & $T r / E T$ & $E / E T$ \\
\hline \multirow{5}{*}{$14 \mathrm{M}$} & Initial & $1-42 \mathrm{~d}$ & 42 & 6.3 & 0.15 & 44.7 & 1.06 & 51 & 1.21 & $12.35 \%$ & $87.65 \%$ \\
\hline & Development & $43-57 d$ & 15 & 45 & 3.00 & 4.9 & 0.33 & 49.9 & 3.33 & $90.18 \%$ & $9.82 \%$ \\
\hline & Mid-season & $58-150 \mathrm{~d}$ & 93 & 391.1 & 4.21 & 4.3 & 0.05 & 395.4 & 4.25 & $98.91 \%$ & $1.09 \%$ \\
\hline & Late-season & $151-158 \mathrm{~d}$ & 8 & 15.4 & 1.93 & 0.9 & 0.11 & 16.3 & 2.04 & $94.48 \%$ & $5.52 \%$ \\
\hline & Whole & $1-158 d$ & 158 & 457.8 & 2.90 & 54.8 & 0.35 & 512.6 & 3.24 & $89.31 \%$ & $10.69 \%$ \\
\hline \multirow{5}{*}{$14 \mathrm{~N}$} & Initial & $1-48 d$ & 48 & 7.5 & 0.16 & 82.3 & 1.71 & 89.8 & 1.87 & $8.35 \%$ & $91.65 \%$ \\
\hline & Development & $49-68 d$ & 20 & 48.2 & 2.41 & 24.4 & 1.22 & 72.6 & 3.63 & $66.39 \%$ & $33.61 \%$ \\
\hline & Mid-season & $69-147$ d & 79 & 323.6 & 4.10 & 18.7 & 0.24 & 342.3 & 4.33 & $94.54 \%$ & $5.46 \%$ \\
\hline & Late-season & $148-158 \mathrm{~d}$ & 11 & 21.7 & 1.97 & 2.8 & 0.25 & 24.5 & 2.23 & $88.57 \%$ & $11.43 \%$ \\
\hline & Whole & $1-158 \mathrm{~d}$ & 158 & 401 & 2.54 & 128.2 & 0.81 & 529.2 & 3.35 & $75.77 \%$ & $24.23 \%$ \\
\hline \multirow{5}{*}{$15 \mathrm{M}$} & Initial & $1-37 d$ & 37 & 5.9 & 0.16 & 54.4 & 1.47 & 60.3 & 1.63 & $9.78 \%$ & $90.22 \%$ \\
\hline & Development & $38-59 d$ & 22 & 58.1 & 2.64 & 18.9 & 0.86 & 77 & 3.50 & $75.45 \%$ & $24.55 \%$ \\
\hline & Mid-season & $60-126 \mathrm{~d}$ & 67 & 301 & 4.49 & 12.3 & 0.18 & 313.3 & 4.68 & $96.07 \%$ & $3.93 \%$ \\
\hline & Late-season & $127-156 \mathrm{~d}$ & 30 & 46.2 & 1.54 & 29.6 & 0.99 & 75.8 & 2.53 & $60.95 \%$ & $39.05 \%$ \\
\hline & Whole & $1-156 \mathrm{~d}$ & 156 & 411.2 & 2.64 & 115.2 & 0.74 & 526.4 & 3.37 & $78.12 \%$ & $21.88 \%$ \\
\hline \multirow{5}{*}{$15 \mathrm{~N}$} & Initial & $1-46 \mathrm{~d}$ & 46 & 8.4 & 0.18 & 72.5 & 1.58 & 80.9 & 1.76 & $10.38 \%$ & $89.62 \%$ \\
\hline & Development & $47-71 \mathrm{~d}$ & 25 & 61.5 & 2.46 & 40.7 & 1.63 & 102.2 & 4.09 & $60.18 \%$ & $39.82 \%$ \\
\hline & Mid-season & $72-124 \mathrm{~d}$ & 53 & 236 & 4.45 & 20.2 & 0.38 & 256.2 & 4.83 & $92.12 \%$ & $7.88 \%$ \\
\hline & Late-season & $125-156 \mathrm{~d}$ & 32 & 53.3 & 1.67 & 41.9 & 1.31 & 95.2 & 2.98 & $55.99 \%$ & $44.01 \%$ \\
\hline & Whole & $1-156 \mathrm{~d}$ & 156 & 359.2 & 2.30 & 175.3 & 1.12 & 534.5 & 3.43 & $67.20 \%$ & $32.80 \%$ \\
\hline
\end{tabular}

Higher M Tr indicates that plastic film mulch improved the effective water use of maize or the ratio of $\operatorname{Tr}$ to $E T$, and then biomass production and yield [58]. In another rain-fed maize field, Zhou et al. [59] reported that partly $\left(f_{m}=0.7\right)$ and whole mulching with plastic film reduced total ET by $11.1 \%$ and $16.6 \%$, respectively, comparing with no mulching. Averaged ratio of $E$ to $E T$ for the two years was $28.93 \%$ under no plastic film mulch, which was close to the ratios of no-mulch maize field reported by other researchers with $26.0 \%$ and $30.3 \%$ [16,60]. One of the main reasons for ET reduced by mulching was that the proportion of soil evaporation $(E)$ was reduced. According to the Table 4, film mulch shortened the initial and development stages of maize. That is to say, film mulch could shorten the crop season duration and accelerate the growth of maize.

Equation (5) shows that the product of $C C^{*}$ and $K c_{T r}, x$ was basal crop coefficient $\left(K_{c}{ }_{T r}\right)$ as presented in the FAO 56 [38]. We gave the similar table with the FAO 56 basal crop coefficients (Table 17 in the $F A O 56)$. As shown in the red solid line in Figure 6, the $\mathrm{M} \mathrm{Kc}{ }_{\mathrm{Tr}}$ was significantly higher than that for the $\mathrm{N}$ treatment, which was consistent with the variation of $C C$ curve (Figure 3). Both $\mathrm{Kc}_{\mathrm{Tr}}$ of two conditions were lower in the initial stage, and gradually increased with the advance of the growth stage until reaching the maximum in the mid-season. The adjusted Ke was shown in the dotted line in Figure 6. The change trend of $K e$ was relatively consistent with that of $E$.

Table 5 presented stage-averaged $K c_{T r}$, Ke, and $K c . K c_{T r}$ was the largest in the mid-season (1.14) and the smallest in the initial stage (0.04). Ke is the largest at the initial stage (0.48) and the smallest at the mid-season stage (0.03). The total $K c$ reached the maximum at the mid-season stage (1.21) and the minimum at the initial stage (0.38). As shown in Table 5, in the initial stage, there was no difference in $K c_{T r}$ between the two treatments, and $K e$ was reduced by $29.17 \%$ with plastic film mulch. In the development stage, the advantages of laminating were gradually shown. Laminating increased $K c \mathrm{Tr}$ by $3.33 \%$ and decreased $K e$ by $63.89 \%$. In the middle-season, the $K c \operatorname{Tr}$ was increased by $0.88 \%$ and the Ke was reduced by $62.50 \%$ by the plastic film mulch. In the late-season Ke was reduced by $32.26 \%$ by plastic film mulch, while for $K c_{T r}$, there were pests and diseases in 2015, and plastic film mulch did not improve $K c_{T r}$. 

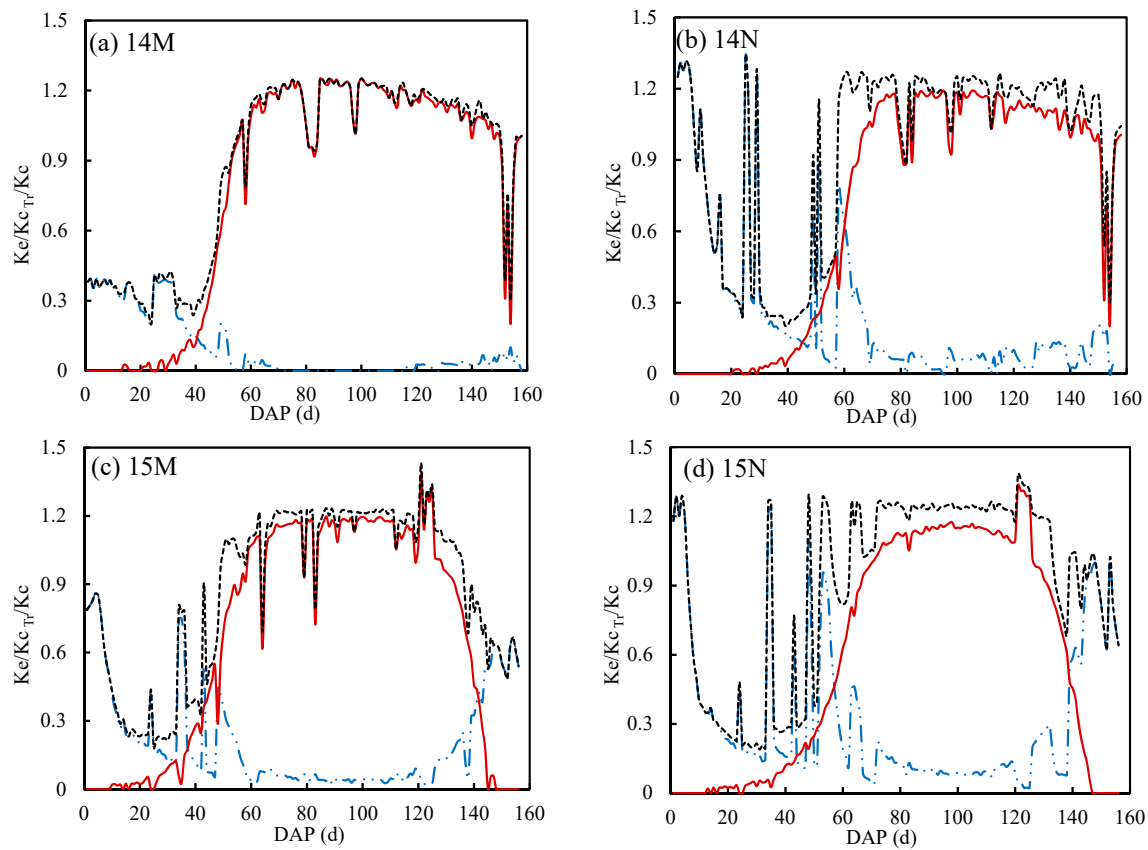

Figure 6. Variations in daily crop coefficient components against DAP of seed maize partitioned for treatments with and without plastic film mulch (M and N) in 2014 to 2015, including crop coefficient $K_{c}$ (- - - - - -), soil evaporation coefficient $K e(-. \cdot-\cdot-. \cdot-)$ and transpiration coefficient $K c_{T r}(-)$.

Table 5. Mean crop coefficient $K c$, transpiration coefficient $K_{c}{ }_{T r}$, soil evaporation coefficient $K e$ of seed maize in different growth stages for treatments with and without plastic film mulch (M and N).

\begin{tabular}{cccccc}
\hline Components & Treatments & Initial & Development & Mid-Season & Late-Season \\
\hline \multirow{2}{*}{$K e$} & M & 0.34 & 0.13 & 0.03 & 0.21 \\
& N & 0.48 & 0.36 & 0.08 & 0.31 \\
\hline \multirow{2}{*}{$K c T r$} & M & 0.04 & 0.62 & 1.14 & 0.58 \\
& N & 0.04 & 0.60 & 1.13 & 0.63 \\
\hline \multirow{2}{*}{$K c$} & M & 0.38 & 0.76 & 1.17 & 0.79 \\
& N & 0.52 & 0.96 & 1.21 & 0.94 \\
\hline
\end{tabular}

\section{Conclusions}

The AquaCrop model performed well for simulating CC and ET, and can be used to partition ET and investigate crop growth of seed maize for treatments with and without plastic film mulch. Plastic film mulch increased the GDDays, changed the phenology, advanced the growth stage, increased beneficial $T r$, and reduced $E$, which was not conducive to seed maize and $E T$ during the growth period of seed maize, resulting in improved water use effectiveness (EUW).

Author Contributions: Designed the experiments and analyzed the data: Q.S. and R.D. Contributed reagents/materials/analysis tools: R.D., T.D., L.T. and S.L. Wrote the manuscript: Q.S., R.D., T.D., L.T. and S.L.

Funding: This research was partially supported by the National Natural Science Foundation of China (51679237, 51790534 and 51621061), the Government Public Research Funds for Projects (201503125), and China Agriculture Research System (CARS-03-35). The funders had no role in study design, data collection and analysis, decision to publish, or preparation of the manuscript.

Acknowledgments: We thank the two anonymous reviewers for their constructive comments that have helped to improve the manuscript.

Conflicts of Interest: The authors declare no conflict of interest. 


\section{References}

1. Sinclair, T.R.; Devi, J.; Shekoofa, A.; Choudhary, S.; Sadok, W.; Vadez, V.; Riar, M.; Rufty, T. Limited-transpiration response to high vapor pressure deficit in crop species. J. Cit. Rep. 2017, 260, 109-118. [CrossRef] [PubMed]

2. Lobell, D.B.; Roberts, M.J.; Schlenker, W.; Braun, N.; Little, B.B.; Rejesus, R.M.; Hammer, G.L. Greater sensitivity to drought accompanies maize yield increase in the US Midwest. Science 2014, 344, 516-519. [CrossRef]

3. Leuning, R.; Zhang, Y.Q.; Rajaud, A.; Cleugh, H.; Tu, K. A simple surface conductance model to estimate regional evaporation using MODIS leaf area index and the Penman-Monteith equation. Water Resour. Res. 2008, 44, W10419. [CrossRef]

4. Liu, H.J.; Yang, H.Y.; Zheng, J.H.; Jia, D.D.; Wang, J.; Li, Y.; Huang, G.H. Irrigation scheduling strategies based on soil matric potential on yield and fruit quality of mulched-drip irrigated chili pepper in Northwest China. Agric. Water Manag. 2012, 115, 232-241. [CrossRef]

5. Rana, G.; Katerji, N. Measurement and estimation of actual evapotranspiration in the field under Mediterranean climate: A review. Eur. J. Agron. 2000, 13, 125-153. [CrossRef]

6. Allen, R.G. Using the FAO-56 dual crop coefficient method over an irrigated region as part of an evapotranspiration intercomparison study. J. Hydrol. 2000, 229, 27-41. [CrossRef]

7. Ding, R.S.; Kang, S.Z.; Li, F.S.; Zhang, Y.Q.; Tong, L. Evapotranspiration measurement and estimation using modified Priestley-Taylor model in an irrigated maize field with mulching. Agric. For. Meteorol. 2013, 168, 140-148. [CrossRef]

8. Pieruschka, R.; Huber, G.; Berry, J.A. Control of transpiration by radiation. In Proceedings of the National Academy of Sciences of The United States of America, Stanford, CA, USA, 16 June 2010; Volume 107, pp. 13372-13377.

9. Er-Raki, S.; Chehbouni, A.; Boulet, G.; Williams, D.G. Using the dual approach of FAO-56 for partitioning ET into soil and plant components for olive orchards in a semi-arid region. Agric. Water Manag. 2010, 97, 1769-1778. [CrossRef]

10. Katerji, N.; Campi, P.; Mastrorilli, M. Productivity, evapotranspiration, and water use efficiency of corn and tomato crops simulated by AquaCrop under contrasting water stress conditions in the Mediterranean region. Agric. Water Manag. 2013, 130, 14-26. [CrossRef]

11. Jones, J.W.; Hoogenboom, G.; Porter, C.H.; Boote, K.J.; Batchelor, W.D.; Hunt, L.A.; Wilkens, P.W.; Singh, U.; Gijsman, A.J.; Ritchie, J.T. The DSSAT cropping system model. Eur. J. Agron. 2003, 18, 235-265. [CrossRef]

12. Diepen, C.A.; Wolf, J.; Keulen, H.; Rappoldt, C. WOFOST: A simulation model of crop production. Soil Use Manag. 1989, 5, 16-24. [CrossRef]

13. Keating, B.A.; Carberry, P.S.; Hammer, G.L.; Probert, M.E.; Robertson, M.J.; Holzworth, D.; Huth, N.I.; Hargreaves, J.N.G.; Meinke, H.; Hochman, Z.; et al. An overview of APSIM, a model designed for farming systems simulation. Eur. J. Agron. 2003, 18, 267-288. [CrossRef]

14. Sharpley, A.N.; Williams, J.R. EPIC-Erosion/Productivity Impact Calculator: 1. Model Documentation; Technical Bulletin-United States Department of Agriculture; Agricultural Research Service: Beltsville, MA, USA, 1990.

15. Ko, J.; Piccinni, G.; Steglich, E. Using EPIC model to manage irrigated cotton and maize. Agric. Water Manag. 2009, 96, 1323-1331. [CrossRef]

16. Kang, S.; Zhang, L.; Liang, Y.; Dawes, W. Simulation of winter wheat yield and water use efficiency in the Loess Plateau of China using WAVES. Agric. Syst. 2003, 78, 355-367. [CrossRef]

17. Stöckle, C.O.; Donatelli, M.; Nelson, R. CropSyst, a cropping systems simulation model. Eur. J. Agron. 2003, 18, 289-307. [CrossRef]

18. Steduto, P.; Hsiao, T.C.; Raes, D.; Fereres, E. AquaCrop-The FAO crop model to simulate yield response to water: I. Concepts and underlying principles. Agron. J. 2009, 101, 426-437. [CrossRef]

19. Raes, D.; Steduto, P.; Hsiao, T.C.; Fereres, E. AquaCrop-the FAO crop model to simulate yield response to water: II. Main algorithms and software description. Agron. J. 2009, 101, 438-447. [CrossRef]

20. Stricevic, R.; Cosic, M.; Djurovic, N.; Pejic, B.; Maksimovic, L. Assessment of the FAO AquaCrop model in the simulation of rainfed and supplementally irrigated maize, sugar beet and sunflower. Agric. Water Manag. 2011, 98, 1615-1621. [CrossRef] 
21. Nyakudya, I.W.; Stroosnijder, L. Effect of rooting depth: Plant density and planting date on maize (zea mays L.) yield and water use efficiency in semi-arid Zimbabwe: Modelling with AquaCrop. Agric. Water Manag. 2014, 146, 280-296. [CrossRef]

22. Abedinpour, M.; Sarangi, A.; Rajput, T.B.S.; Singh, M.; Pathak, H.; Ahmad, T. Performance evaluation of AquaCrop model for maize crop in a semi-arid environment. Agric. Water Manag. 2012, 110, 55-66. [CrossRef]

23. Hsiao, T.C.; Heng, L.; Steduto, P.; Rojas-Lara, B.; Raes, D.; Fereres, E. AquaCrop-the FAO crop model to simulate yield response to water: III. Parameterization and testing for maize. Agron. J. 2009, 101, 448-459. [CrossRef]

24. Paredes, P.; de Melo-Abreu, J.P.; Alves, I.; Pereira, L.S. Assessing the performance of the FAO AquaCrop model to estimate maize yields and water use under full and deficit irrigation with focus on model parameterization. Agric. Water Manag. 2014, 144, 81-97. [CrossRef]

25. Mkhabela, M.S.; Bullock, P.R. Performance of the FAO AquaCrop model for wheat grain yield and soil moisture simulation in Western Canada. Agric. Water Manag. 2012, 110, 16-24. [CrossRef]

26. Wang, X.; Wang, Q.; Fan, J.; Fu, Q. Evaluation of the AquaCrop model for simulating the impact of water deficits and different irrigation regimes on the biomass and yield of winter wheat grown on China's Loess Plateau. Agric. Water Manag. 2013, 129, 95-104.

27. Andarzian, B.; Bannayan, M.; Steduto, P.; Mazraeh, H.; Barati, M.E.; Barati, M.A.; Rahnama, A. Validation and testing of the AquaCrop model under full and deficit irrigated wheat production in Iran. Agric. Water Manag. 2011, 100, 1-8. [CrossRef]

28. Iqbal, M.A.; Shen, Y.; Stricevic, R.; Pei, H.; Sun, H.; Amiri, E.; Penas, A.; Rio, S. Evaluation of the FAO AquaCrop model for winter wheat on the North China Plain under deficit irrigation from field experiment to regional yield simulation. Agric. Water Manag. 2014, 135, 61-72. [CrossRef]

29. Toumi, J.; Er-Raki, S.; Ezzahar, J.; Khabba, S.; Jarlan, L.; Chehbouni, A. Performance assessment of AquaCrop model for estimating evapotranspiration, soil water content and grain yield of winter wheat in Tensift $\mathrm{Al}$ Haouz (Morocco): Application to irrigation management. Agric. Water Manag. 2016, 163, 219-235. [CrossRef]

30. Linker, R.; Ioslovich, I.; Sylaios, G.; Plauborg, F.; Battilani, A. Optimal model-based deficit irrigation scheduling using AquaCrop: A simulation study with cotton, potato and tomato. Agric. Water Manag. 2016, 163, 236-243. [CrossRef]

31. Garcia-Vila, M.; Fereres, E.; Mateos, L.; Orgaz, F.; Steduto, P. Deficit irrigation optimization of cotton with AquaCrop. Agron. J. 2009, 101, 477-487. [CrossRef]

32. Maniruzzaman, M.; Talukder, M.S.U.; Khan, M.H.; Biswas, J.C.; Nemes, A. Validation of the AquaCrop model for irrigated rice production under varied water regimes in Bangladesh. Agric. Water Manag. 2015, 159, 331-340. [CrossRef]

33. Todorovic, M.; Albrizio, R.; Zivotic, L.; Saab, M.T.A.; Stöckle, C.; Steduto, P. Assessment of AquaCrop, CropSyst, and WOFOST models in the simulation of sunflower growth under different water regimes. Agron. J. 2009, 101, 509-521. [CrossRef]

34. Araya, A.; Keesstra, S.D.; Stroosnijder, L. Simulating yield response to water of Teff (Eragrostis tef) with FAO's AquaCrop model. Field Crops Res. 2010, 116, 196-204. [CrossRef]

35. Dong, H.Z.; Li, W.J.; Tang, W.; Zhang, D.M. Early plastic mulching increases stand establishment and lint yield of cotton in saline fields. Field Crops Res. 2009, 111, 269-275. [CrossRef]

36. Zhao, W.; Liu, B.; Zhang, Z. Water requirements of maize in the middle Heihe River basin, China. Agric. Water Manag. 2010, 97, 215-223. [CrossRef]

37. Hou, X.Y.; Wang, F.X.; Han, J.J.; Kang, S.Z.; Feng, S.Y. Duration of plastic mulch for potato growth under drip irrigation in an arid region of Northwest China. Agric. For. Meteorol. 2010, 150, 115-121. [CrossRef]

38. Allen, R.G.; Pereira, L.S.; Raes, D.; Smith, M. Crop evapotranspiration. guide-lines for computing crop water requirements. In FAO Irrigation and Drainage Paper 56; Food and Agriculture Organization of United Nations: Rome, Italy, 1998.

39. Paredes, P.; Wei, Z.; Liu, Y.; Xu, D.; Xin, Y.; Zhang, B.; Pereira, L.S. Performance assessment of the FAO AquaCrop model for soil water, soil evaporation, biomass and yield of soybeans in North China plain. Agric. Water Manag. 2015, 152, 57-71. [CrossRef] 
40. Pereira, L.S.; Paredes, P.; Rodrigues, G.C.; Neves, M. Modeling malt barley water use and evapotranspiration partitioning in two contrasting rainfall years. Assessing AquaCrop and SIMDualKc models. Agric. Water Manag. 2015, 159, 239-254. [CrossRef]

41. Ran, H.; Kang, S.Z.; Li, F.S.; Tong, L.; Ding, R.S.; Du, T.S.; Li, S.E.; Zhang, X.T. Performance of AquaCrop and SIMDualKc models in evapotranspiration partitioning on full and deficit irrigated maize for seed production under plastic film-mulch in an arid region of China. Agric. Syst. 2017, 151, 20-32. [CrossRef]

42. Campolongo, F.; Cariboni, J.; Saltelli, A. An effective screening design for sensitivity analysis of large models. Environ. Model. Softw. 2007, 22, 1509-1518. [CrossRef]

43. Confalonieri, R.; Bellocchi, G.; Tarantola, S.; Acutis, M.; Donatelli, M.; Genovese, G. Sensitivity analysis of the rice model WARM in Europe: Exploring the effects of different locations, climates and methods of analysis on model sensitivity to crop parameters. Environ. Model. Softw. 2010, 25, 479-488. [CrossRef]

44. Saltelli, A.; Ratto, M.; Andres, T.; Campolongo, F.; Cariboni, J.; Gatelli, D.; Saisana, M.; Tarantola, S. Global Sensitivity Analysis: The Primer; John Wiley: Chichester, UK, 2008; p. 292.

45. Saltelli, A.; Annoni, P. How to avoid a perfunctory sensitivity analysis. Environ. Model. Softw. 2010, 25, 1508-1517. [CrossRef]

46. Cariboni, J.; Gatelli, D.; Liska, R.; Saltelli, A. The role of sensitivity analysis in ecological modelling. Ecol. Model. 2007, 203, 167-182. [CrossRef]

47. Elsawwaf, M.; Willems, P.; Feyen, J. Assessment of the sensitivity and prediction uncertainty of evaporation models applied to Nasser Lake, Egypt. J. Hydrol. 2010, 395, 10-22. [CrossRef]

48. Saltelli, A.; Tarantola, S.; Campolongo, F. Sensitivity analysis as an ingredient of modeling. Stat. Sci. 2000, 15, 377-395.

49. Morris, M.D. Factorial sampling plans for preliminary computational experiments. Technometrics 1991, 33, 161-174. [CrossRef]

50. Sobol, I.M. Sensitivity estimates for nonlinear mathematical models. Math. Model. Comput. Exp. 1993, 1, 407-414.

51. Kendall, C.D.; James, C.A. II.; Mehdi, A.; Allan, A.A.; Mazdak, A. Global sensitivity and uncertainty analysis of a dynamic agroecosystem model under different irrigation treatments. Ecol. Model. 2012, 231, 113-125.

52. Rosa, R.D.; Paredes, P.; Rodrigues, G.C.; Fernando, R.M.; Alves, I.; Pereira, L.S.; Allen, R.G. Implementing the dual crop coefficient approach in interactive software: 2. Model testing. Agric. Water Manag. 2012, 103, 62-77. [CrossRef]

53. Nash, J.E.; Sutcliffe, J.V. River flow forecasting through conceptual models part I-A discussion of principles. J. Hydrol. 1970, 10, 282-290. [CrossRef]

54. Willmott, C.J. On the validation of models. Phys. Geogr. 1981, 2, 184-194. [CrossRef]

55. Zeleke, K.T.; Luckett, D.; Cowley, R. Calibration and testing of the FAO AquaCrop model for canola. Agron. J. 2011, 103, 1610-1618. [CrossRef]

56. Farahani, H.J.; Izzi, G.; Oweis, T.Y. Parameterization and evaluation of the AquaCrop model for full and deficit irrigated cotton. Agron. J. 2009, 101, 469-476. [CrossRef]

57. Abi Saab, N.T.; Todorovic, M.; Albrizio, R. Comparing AquaCrop and CropSyst models in simulating barley growth and yield under different water and nitrogen regimes. Does calibration year influence the performance of crop growth models? Agric. Water Manag. 2015, 147, 21-33. [CrossRef]

58. Fan, Y.Q.; Ding, R.S.; Kang, S.Z.; Hao, X.M.; Du, T.S.; Tong, L. Plastic mulch decreases available energy and evapotranspiration and improves yield and water use efficiency in an irrigated maize cropland. Agric. Water Manag. 2017, 179, 122-131. [CrossRef]

59. Zhou, L.M.; Li, F.M.; Jin, S.L.; Song, Y.J. How two ridges and the furrow mulched with plastic film affect soil water, soil temperature and yield of maize on the semiarid Loess Plateau of China. Field Crops Res. 2009, 113, 41-47. [CrossRef]

60. Liu, C.; Zhang, X.; Zhang, Y. Determination of daily evaporation and evapotranspiration of winter wheat and maize by large-scale weighing lysimeter and micro-lysimeter. Agric. For. Meteorol. 2002, 111, 109-120. [CrossRef]

(C) 2019 by the authors. Licensee MDPI, Basel, Switzerland. This article is an open access article distributed under the terms and conditions of the Creative Commons Attribution (CC BY) license (http://creativecommons.org/licenses/by/4.0/). 